\title{
Japan watching
}

\section{3 was a record year for Pig iron and steel production}

The advent of the energy crisis was expected by many to have a severe effect on the pig iron and crude steel production during the last quarter of 1973 , however, the sharp curtailment of production did not take place and new production records were recorded in all areas. The crude steel production totalled 119,325,000 metric tons, an increase of $22,430,000$ tons over the production of 1972 . This increase in production is some $23.1 \%$ of the 1972 total. For the Japanese industry 1973 was a milestone, as it was the first year in which over one hundred million tons of steel had been produced. Japan, therefore, joined the select group that formerly consisted of only the US and the USSR.

The production of pig iron was not affected by the energy crisis as the record monthly production rate came in December when $7,928,000$ metric tons were poured, an increase of $1.8 \%$ over November, the former record month. The total pig iron production during 1973 came to $89,675,000$ metric tons, an increase of about 16 million tons over 1972. The uptrend in the blast furnace pig iron production is mainly attributed to the start-up of new furnaces. The driving rate was also at record levels as the production per cu meter of working volume set a new record, 2.04 metric tons per cu meter. The former record was 1.95 established in 1970. Many furnaces operated at near the 2.5 ton per cu meter level.

Foundry pig iron accounted for 1.9 million tons of the total, only about $2.1 \%$. More than $99 \%$ of the production was by blast furnaces with electric furnaces and cupolas accounting for the remainder.

The crude steel production in $\mathrm{De}$ cember was 10,305,000 metric tons, almost exactly the same as in November, the record month. Basic oxygen converters were used to produce some $80.5 \%$ of all steel. The BOF production was $96,050,000$ tons, an increase of $23.1 \%$ over the production in 1972 . Open hearth furnaces were used to produce only 1.9 million tons of steel; a decrease of about $3 \%$ from last year. The electric furnaces were employed in the production of $21,420,000$ tons of crude steel, an increase of about $19 \%$ over last year but still a smaller proportion of the total than in the previous year.

Electric furnace steel production suffered far greater than the converter operation in the energy related cut backs experienced in December.

The production of ordinary hot rolled steel products totalled $91,040,000$ metric tons, increasing some 17.4 million tons or $23.7 \%$ over 1972 . Particularly outstanding increases occurred in heavy rails, up $60 \%$, large $H$ shapes, up $40 \%$, and medium plates, up $36 \%$.

\section{Steelmaking raw material costs Rose by $60 \%$ during 1973}

Based on the figures released by the Japan Iron and Steel Federation, the costs of steelmaking raw materials rose by nearly $60 \%$ during 1973 . This is an increase from the $\$ 47.50$ level to the $\$ 75.70$ per ton of steel product.

The price of iron ore increased by $40 \%$, coking coal $160 \%$, heavy oil by $190 \%$, and steel scrap by $230 \%$ over the prices paid in 1972 . The federation stated that the raw materials costs account for $65 \%$ of the total cost increases experienced by the industry. The total cost increases experienced by the industry, including raw material, labor, equipment, and environmental preservation expenses, came to about $\$ 43.00$ per ton of steel product.

\section{Ferro Alloy industry operated at Record levels during 1973}

The Ferro-Alloy Association recently provided production figures for 1973 that show the industry operated at record levels throughout 1973. A new record for total production during a fiscal year is expected when FY 1973 ends on March 30th. The record 2.1 million tons will be some $33 \%$ higher than the 1.6 million tons produced in 1972 . The Association stated that electric power and oil use restrictions during the final quarter caused a production loss of nearly 100,000 tons from the original plans. The following table gives the production of the main ferro alloys during 1972 and 1973:

\begin{tabular}{|c|c|c|}
\hline \multirow[b]{2}{*}{ Ferro Alloy } & \multirow{2}{*}{\multicolumn{2}{|c|}{$\begin{array}{c}\text { Production } \\
(1,000 \mathrm{MT})\end{array}$}} \\
\hline & & \\
\hline $\begin{array}{l}\text { Ferro Manganese } \\
\text { High Carbon } \\
\text { Medium and low Carbon } \\
\text { Silico Manganese } \\
\text { Ferro Silicon }\end{array}$ & $\begin{array}{l}431.3 \\
129.4 \\
349.3 \\
322.5\end{array}$ & $\begin{array}{l}505.2 \\
143.1 \\
529.7 \\
344.4\end{array}$ \\
\hline $\begin{array}{l}\text { Ferro Chrome. } \\
\text { High Carboon } \\
\text { Low Carbon } \\
\text { Silico Chrome }\end{array}$ & $\begin{array}{r}256.7 \\
76.3 \\
32.1\end{array}$ & $\begin{array}{r}431.7 \\
85.3 \\
85.0\end{array}$ \\
\hline Total & $\overline{1,597.7}$ & $\overline{2,124.2}$ \\
\hline
\end{tabular}

\section{Nippon Kokan KK tries reducing Gas injection in blast furnace}

Injection of a reducing gas directly into the stack of blast furnaces is a technique that combines the advantages of both the blast furnace and the shaft reducing furnace and permits significant savings in coke. NKK has experienced a standard coke rate of about $571 \mathrm{~kg}$ per ton of hot metal in normal blast furnace operation. In the experimental blast furnace the coke rate was reduced to $360 \mathrm{~kg}$ per ton of hot metal by injecting a reducing gas directly into the shaft at a rate of $628 \mathrm{cu}$ meters per ton of hot metal. The injection of re- ducing gas into the stack increased the furnace production at a $8 \%$ rate for every $100 \mathrm{cu}$ meters per ton of hot metals.

The injection of gas into the stack allowed a equivalent reduction in blast through the tuyeres, thereby permitting reduction in size of the needed blowers and hot stoves as well as improving the permeability in the melting zone of the furnace.

NKK produced the reducing gas by partially oxidizing heavy oil with oxygen to provide a gas of 3 to $4 \%$ carbon dioxide, $7 \%$ water, at a temperature of 1,200 to 1,300 degrees centigrade.

The penetrating depth of the reducing gas was proportional to the volume of injected gas. The diffusion throughout the stack presented no problems.

The cost of the reducing gas produced in these NKK experiments indicated the need to utilize a cheaper source than heavy oil.

\section{Japan had largest 1973 Steel production increase}

The Japan Iron and Steel Federation recently published its tabulation of the steel production during 1973 achieved by each nation. This tabulation shows that the increase in production of 22.4 million tons achieved by the Japanese industry was by far the largest. This increase is a massive $22.8 \%$ over the 1972 production. The 119.3 million tons produced in Japan raised the share of the world production to $17.1 \%$. The increase in Japanese production was double the $11.1 \%$ worldwide increase that brought the total production in 1973 up to the 697 million ton level. The United States lead the production race both in total quantity, 136 million tons, and share of the production, $19.5 \%$. The following table production and increase over 1972 for the major producers in the world:

\begin{tabular}{|c|c|c|}
\hline Country & $\begin{array}{c}\text { Production, } \\
1973 \\
(1,000 \mathrm{MT})\end{array}$ & $\begin{array}{c}\text { Increase } \\
\text { Over } \\
1972(\%)\end{array}$ \\
\hline $\begin{array}{l}\text { United States } \\
\text { USSR } \\
\text { Japan } \\
\text { West Germany } \\
\text { United Kingdom } \\
\text { China } \\
\text { France } \\
\text { Italy } \\
\text { Belgium } \\
\text { Poland } \\
\text { Canada } \\
\text { Czechoslovakia } \\
\text { Spain } \\
\text { Romania } \\
\text { Australia } \\
\text { Brazil } \\
\text { India } \\
\text { East Germany } \\
\text { Luxembourg } \\
\text { Sweden } \\
\text { The Netherlands } \\
\text { South Africa } \\
\text { Mexico } \\
\text { Austria } \\
\text { Hungary } \\
\text { North Korea } \\
\text { Yugoslavia } \\
\text { Bulgaria } \\
\text { Argentina } \\
\text { Finland } \\
\text { Turkey } \\
\text { Venezuela } \\
\text { Others }\end{array}$ & $\begin{array}{r}136,000 \\
131,500 \\
119,325 \\
49,519 \\
26,674 \\
26,000 \\
25,300 \\
20,010 \\
15,526 \\
14,000 \\
13,550 \\
13,300 \\
11,500 \\
8,000 \\
7,600 \\
7,200 \\
6,800 \\
6,400 \\
5,925 \\
5,700 \\
5,600 \\
5,600 \\
4,600 \\
4,300 \\
3,300 \\
2,900 \\
2,800 \\
2,300 \\
2,150 \\
1,600 \\
1,350 \\
1,100 \\
6,371 \\
\end{array}$ & $\begin{array}{r}12.5 \\
4.8 \\
22.8 \\
13.3 \\
5.3 \\
13.0 \\
5.2 \\
1.0 \\
6.8 \\
4.3 \\
14.3 \\
4.5 \\
21.0 \\
8.1 \\
11.3 \\
10.4 \\
3.0 \\
5.8 \\
8.6 \\
8.5 \\
0.3 \\
4.9 \\
5.4 \\
5.7 \\
0.8 \\
9.4 \\
8.2 \\
8.4 \\
2.1 \\
9.9 \\
3.6 \\
0.5 \\
10.7 \\
\end{array}$ \\
\hline Total & $\overline{697,000}$ & 11.1 \\
\hline
\end{tabular}

